7-2008

\title{
Using Scholarship of Teaching and Learning (SoTL) to Inquire Into Pre-service Teachers' Science Lesson Planning Considerations
}

Geeta Verma

Georgia State University, gverma@gsu.edu

Follow this and additional works at: https://digitalcommons.georgiasouthern.edu/ij-sotl

\section{Recommended Citation}

Verma, Geeta (2008) "Using Scholarship of Teaching and Learning (SoTL) to Inquire Into Pre-service Teachers' Science Lesson Planning Considerations," International Journal for the Scholarship of Teaching and Learning: Vol. 2: No. 2, Article 10.

Available at: https://doi.org/10.20429/ijsotl.2008.020210 


\title{
Using Scholarship of Teaching and Learning (SoTL) to Inquire Into Pre-service Teachers' Science Lesson Planning Considerations
}

\author{
Abstract \\ This paper shares my experiences with the scholarship of teaching and learning (SoTL) framework in my \\ university science methods course. Incorporating SoTL not only enabled me to inquire into my own \\ teaching as a scholarly activity but also engaged my students in critical reflections. I used the principles \\ and characteristics of SoTL to design this inquiry by; a) creating a new instructional framework for lesson \\ planning; b) facilitating students' reflections on their experiences with the new framework; and c) \\ documenting and presenting this inquiry as a scholarly activity. Forty-eight pre service teachers $(\mathrm{N}=48)$, \\ 43 women and 5 men participated in this inquiry. Qualitative data was collected and analyzed \\ simultaneously over a period of three semesters to critically inform the inquiry. Data comprised of pre- \\ service teachers' reflective pieces, personal interviews, and lesson plans. Results indicated that pre- \\ service teachers' experiences with the new instructional framework was challenging and rewarding at the \\ same time. Data also indicated that some participants identified a disconnect between lesson plan \\ writing and teaching processes. My engagement with the SoTL indicated that the new instructional \\ framework helped pre-service teachers to engage critically with Pedagogical Content Knowledge (PCK) \\ and increased their comfort level in science teaching.
}

\section{Keywords}

Pre-service teacher education, Science education, Scholarship of teaching and learning, Lesson plan writing, Pedagogical content knowledge

\section{Creative Commons License} c) (i) $\Theta$

This work is licensed under a Creative Commons Attribution-Noncommercial-No Derivative Works 4.0 License. 


\title{
Using Scholarship of Teaching and Learning (SOTL) to I nquire I nto Pre-service Teachers' Science Lesson Planning Considerations
}

\begin{abstract}
This paper shares my experiences with the scholarship of teaching and learning (SoTL) framework in my university science methods course. Incorporating SoTL not only enabled me to inquire into my own teaching as a scholarly activity but also engaged my students in critical reflections. I used the principles and characteristics of SoTL to design this inquiry by a) creating a new instructional framework for lesson planning; b) facilitating students' reflections on their experiences with the new framework; and c) documenting and presenting this inquiry as a scholarly activity. Forty-eight pre service teachers $(N=48), 43$ women and 5 men participated in this inquiry. Qualitative data was collected and analyzed simultaneously over a period of three semesters to critically inform the inquiry. Data comprised of pre-service teachers' reflective pieces, personal interviews, and lesson plans. Results indicated that pre-service teachers' experiences with the new instructional framework was challenging and rewarding at the same time. Data also indicated that some participants identified a disconnect between lesson plan writing and teaching processes. My engagement with the SoTL indicated that the new instructional framework helped preservice teachers to engage critically with Pedagogical Content Knowledge (PCK) and increased their comfort level in science teaching.
\end{abstract}

Key Words: Pre-service teacher education, Science Education, Scholarship of Teaching and Learning, Lesson plan writing, Pedagogical Content Knowledge

\section{Introduction}

Science education reform documents (National Research Council [NRC], 1996; American Association for Advancement of Science [AAAS], 1993) highlight 'science for all Americans' as the key guiding principle. These reform documents also outline the guiding principles for pre-service (future teachers) and in-service (current teachers) teacher training since the quality of science instruction is critically important for the scientific and technical literacy of students (Cox \& Carpenter, 1989). Reform-guided teacher preparation programs and ongoing professional development opportunities are important since science teachers play a key role in facilitating the reform initiatives in the science classrooms. These programs and opportunities can successfully prepare teachers by integrating content knowledge with sound instructional and pedagogical strategies.

I have been teaching elementary science methods courses for pre-service undergraduate teachers for the past several years. During this time, I repeatedly found that these teachers not only have a weak mastery of the science content knowledge, they also are not comfortable teaching science in the classroom settings. Jones \& Levin (1994) support these observations in that many elementary teachers are anxious about teaching science due to their own inadequate science background (Archbald \& Porter, 1994; Radford, 1998). Additionally, teachers' own experiences as students in the science classrooms may shape and develop their beliefs about teaching. Therefore, it may be challenging for many teachers to implement reform-based practices in their science classrooms especially if they didn't experience these practices as students. Pajares (1992) posits that teacher held beliefs influence their own perceptions and judgments, which in turn, affect their behavior in the 
classroom. Teachers may continue to feel ill-prepared to teach science in the classroom if their inadequacies in mastering the science content and pedagogy are left unaddressed. One way to help teachers overcome the inadequacies is by providing experiences that explicitly allow them to integrate content and pedagogy followed by reflection and discussions in teacher preparation programs.

In my science methods courses, I incorporate multi-faceted learning opportunities such as mini-research projects, diversity projects, creating science fairs, and integrating informal settings such as use of science museums. However, I never ventured into a systematic inquiry into the effectiveness of these opportunities. Course evaluations for my methods courses were very positive and student comments also indicated that they benefited from taking the course. However, I continued to be troubled by elementary pre-service teachers' low confidence and the lack of comfort in teaching science. During my informal conversations with students, I identified that the students' limited experiences in integrating content knowledge and pedagogical strategies was one of the key factors for the lack of confidence. Therefore, I wondered if I could address these challenges by intentionally providing a 'space' using the lesson planning activity in my course. Lesson planning is an integral part of my methods course and it could be the ideal medium. Using a revised instructional framework for lesson planning activity could probably be the most effective way for students to negotiate both content and pedagogical challenges. The lesson planning framework that I had been using was the standard format used in many methods courses and included components such as general goals, instructional objectives, required materials, student engagement activities, detail plan of the lesson, and closure. It had worked well for me for the most part except that I found out that even after writing multiple lesson plans using this format, many students in the methods course still felt very anxious about teaching science in the classroom.

As I designed the revised instructional framework, I became very interested in finding a scholarly framework that would allow me to chronicle this process, reflect on students' experiences as a scholarly activity which in turn will inform my practice. In this paper, I share a) pre-service teachers' (my students) experiences as they engaged with a new instructional framework for lesson planning; and, b) my reflections on their experiences to critically inform and shape my own practice. I use Shulman's (2002) idea that the scholarship of teaching carries a moral dimension or 'pedagogical imperative' in that an educator must examine the impact of his/her work to maintain the integrity of his/her work. I play the dual role of an instructor and a researcher using the Scholarship of Teaching and Learning (SoTL) framework. As the instructor, I carefully revised the lesson planning instructional framework using four components: a) National Science Education Standards (National Science Teachers Association [NSTA], 1996); b) Bloom's taxonomy (Bloom, 1956); c) the Learning cycle (Novak \& Gowin, 1984; Rubba, 1992); and, d) Concept maps (Rye and Rubba, 1988). The decision to incorporate the four components stemmed from the fact that a deeper understanding of pedagogical tools (Bloom's taxonomy, concept map, and the learning cycle) and resources (NSES) may help the pre-service teachers overcome their low comfort level in science teaching as well as enhance their pedagogical content knowledge (PCK) (Shulman, 1987). PCK is defined 'as the knowledge that is developed by teachers to help others learn' (Abell, 2007, p. 1107). As a researcher, I purposefully collected and analyzed data to meaningfully inform the inquiry into my own practice. I wanted to first explore the role of a new instructional framework on pre-service teachers' comfort in teaching science. Secondly, I wanted to find out if the revised lesson planning framework facilitated students' engagement and mastery of science PCK understandings. Using the SoTL as the scholarly framework allowed me to meet both of these goals. 
The SoTL framework allowed me to coalesce the theory and practice of this inquiry by not only enabling me to implement a new practice in my course, but by also helping me to inquire into this practice through systematic data collection, analysis and discussion of the results. It allowed me to reflectively assess the learning opportunities I provided to their students. My hope is that engaging in this reflective process will facilitate meaningful learning opportunities for the future students in my methods course. Through this reflection, not only did I engage in 'inquiry into student learning' (Huber and Morreale, 2002, p. 9) but I shifted this 'inquiry' in the public sphere by making the work available for review and accessible to others in the field (Gilpin, 2007). Although this was my first attempt at integrating SoTL framework in my university science methods course, I was excited about the opportunity it provided me to delve into my students' experiences as a scholarly activity and to make use of this information critically to shape my own practice. The process was challenging not only in terms of making critical instructional choices but also in deciphering the repercussions of these instructional choices and situating them in students' experiences.

As I navigated the process of putting a revised framework together, I had to make some critical choices such as adopting/adapting existing lesson planning framework such as the " 5 E" model in the literature (Hassard, 2005; Towbridge, Bybee, \& Powell, 2004). Frameworks such as the " $5 \mathrm{E}$ " model (engage, explore, explain, elaborate/extend, and evaluate) are commonly used in science education. I did give the " $5 \mathrm{E}$ " model a serious consideration but decided not to adapt it in my methods course for two reasons. First, the " $5 \mathrm{E}$ " model is geared more toward middle and secondary pre-service teacher, and second it still did not allow me to meet my students' needs in mastering the content and pedagogy integration. Therefore, after serious considerations, I decided to create my own lesson planning instructional framework using the four components (NSES, Blooms' taxonomy, concept mapping, and the learning cycle) to facilitate a robust mastery of science content knowledge and a deeper understandings of the pedagogical skills. The paper is organized in four sections: a) the revised instructional framework; b) the focus questions that guide this inquiry; c) the methods use to guide the inquiry; and d) the results and implication of the inquiry.

\section{Revised I nstructional Framework for the Lesson Plans}

The pre-service teachers in the study were working toward a teaching certification, K-9, leading to elementary education certification. For the science education part of the program, the pre-service teachers took 3-4 science content courses and a science methods course. The science methods course was offered to all the pre-service teachers in the program and all students in the program enrolled in the methods course at some time during the program. During their enrollment in the science methods course they were also placed in a field setting during the semester. They went to their field settings twice a week and were required to teach at least 3-4 lessons to the elementary school students.

As the undergraduate teacher education program followed a non-cohort style, many preservice teachers took a methods course in another content area prior to attending the science methods course. Therefore, many of them were familiar with the components of the revised instructional framework. As a requirement for the science methods course the preservice teachers were required to create three lesson plans using the revised framework. The pre-service teachers chose a topic of their interest for the first lesson plan. The other two lesson plans were created based on the topic/s they taught in their practicum settings 
during the field placement. The revised framework incorporated the following four components (see Appendix A and B for details).

1. National Science Education Standards (NSES) in the instructional/performance obj ectives

2. Bloom's taxonomy in the instructional/performance objectives

3. Learning Cycle in the instructional process (exploratory hands-on, concept development and concept application)

4. Concept map to depict the content covered in the lesson plan.

I provided the background information on each of the four components through class notes, lecture and discussion sessions followed by a few question-answer sessions. I also shared my rationale about implementing the new instructional framework with the teachers in the course and my desire to use SoTL framework to meaningfully inform my own practice. This was done to introduce them to the idea of creating a community of learners to facilitate exchange of ideas in teaching and learning (Huber \& Hutchings, 2005). The next section provides details of the four components.

\section{National Science Education Standards}

The pre-service teachers incorporated the National Science Education Standards (NSTA, 1996) in the instructional/performance objectives of the lesson plans. The NSES standards provide a cohesive vision and guidelines on what science teaching and learning should be and represent a consensus of the nation's science education community. The standards indicate that the focus should be on in-depth understanding of a limited number of topics (rather than a cursory study of a large number of topics) and on hands-on investigations. It was shared that the standards provide guidelines for science teachers to create challenging and engaging curricular experiences for their students (Rakow, 1999). The standards indicate that teachers should no longer be the dispensers of science facts and students are no longer to be passive learners.

\section{Bloom's Taxonomy}

The pre-service teachers incorporated Bloom's taxonomy (1956) in the instructional/ performance objectives to help them create lesson plans that went beyond the knowledge and comprehension skill levels. Bloom's taxonomy challenges educators through the hierarchical classification system in knowledge, comprehension, application, synthesis, analysis, and evaluation levels (Ball \& Washburn, 2001). As Krathwohl (2002) indicates, 'the taxonomy of educational objectives is a framework for classifying statements of what we expect or intent students to learn as a result of instruction' (p. 212). The hierarchal classification system allows one to think about the objectives teachers write in their lesson plans. It can be a meaningful way to organize the learning and performance objectives. Bloom's taxonomy illustrates that learning could be a cyclical, multi-directional process. We may move among the levels of the taxonomy, while revisiting the levels of classification and reexamining what we though we knew and understood (Woods, 1999).

\section{Concept Map}

The pre-service teachers created a concept map covering the science content in the lesson plan. They were asked to align the content in the concept map with the content covered in the instructional/performance objectives and the instructional process. 
Concept mapping was developed as a strategy to probe knowledge structures of learner and can be a used as graphic meta-cognitive tool that provides an external representation of structural knowledge - a visual image - in the form of a two-dimensional semantic network. Novak (1998) argue for the use of concept maps as they allow students to document the changes in their science knowledge over a period of time. Rye and Rubba (1998) indicate that concept maps have emerged as a versatile tool in the area of science education as they seek to investigate students' conceptual understandings. Research also indicates that students who get trained in concept mapping are able to list significantly more concept relationships than students who were not trained (Willerman \& Harg, 1991).

I presented a sample concept map using physical science concepts. This was done as many researchers indicate that concept mapping is more informative, accurate, and complete for students if a sample concept map is provided (Willerman \& Harg, 1991). The course utilized the use of 'Inspiration' software to create concept maps. Inspiration software is an effective tool that allows students to manipulate information for visual learning (J ohnson, 1999). Troutner (1999) has also advocated the use of Inspiration software as it provides 'curriculum-related examples of many graphic organizers' (p. 58).

\section{Learning Cycle}

The pre-service teachers used the 'learning cycle' pedagogical tool to organize the instructional process in the lesson plan. The learning cycle is a widely used science pedagogical strategy for designing learning activities (Rubba, 1992). I used the three-phase design of the learning cycle in the instructional framework. The design has three sequential phases: a) concept exploration; b) concept introduction; and c) concept application. Rubba (1992) describes the details of each of the three phases:

A concept exploration consists of hands-on activities that hold the potential for learners to invent the target concept through self-regulation...In the second phase of a learning cycle, the concept introduction, the target concept of principle is introducing the concept that will allow learners to make sense of the experiences they had in the exploration phase...the third phase of the learning cycle, the concept application, provides learners with opportunities to apply the target concept to additional examples. (p. 98).

In summary, the lesson plan guidelines (Appendix A) and the scoring guidelines (Appendix B) emphasized the importance of integrating the four components to successfully situate the lesson plans in the science education reform documents (AAAS, 1993; NRC, 1996).

\section{Focus Questions}

I wanted to inquire into my own teaching and inform my own practice using the findings from the pre-service teachers' experiences with the lesson plan writing and implementation processes. SoTL allowed me to examine this professional activity by bringing in the idea of 'praxis' (Hooks, 1994). The word 'praxis' means 'practical application of a theory' (Webster dictionary). SoTL framework allowed me to engage in critical reflection and contemplation on my own actions as the 'theory' and then use the reflections to inform my own practice. The participants' experiences in this inquiry provided the input and impetus for this engagement. Therefore, the focus questions in the paper specifically integrate participants' experiences to facilitate my engagement in this endeavor. Two questions guided the study: 
1) How did the pre-service teachers' lesson plan writing experiences shape my understandings of their mastery of Pedagogical Content Knowledge?

2) How did the pre-service teachers' lesson plan implementation experiences in the field shape my understandings of their increased comfort and confidence in teaching science?

\section{Methods}

\section{Setting and Participants}

The inquiry into my own teaching took place at an institution located in an urban setting over a period of three semesters. Forty eight $(\mathrm{N}=48)$ pre-service undergraduate teachers majoring in elementary education took part in the data collection process. The gender and ethnic delineation indicated that $10 \%$ of the participants were males and $90 \%$ were females. Additionally, 78\% of the participants were Caucasian, 11\% African-American, 11\% Latin American, and $1 \%$ Asian American.

\section{Design of the study and Data Collection}

The study used qualitative measures drawing upon naturalistic inquiry and content analysis (Patton, 2002). Understanding the nature of the interaction between pre-service teachers and their experiences in the methods course called for extensive qualitative data collection tools (Guba \& Lincoln, 1989). An emergent design was used since data collection and analysis were ongoing and simultaneous activities (Guba \& Lincoln, 1994) and the process allowed for fuller understanding of participants' experiences (Bogdan and Biklen, 1998; Strauss and Corbin, 1998). The following data sources contributed to my understandings of participants' experiences in lesson writing and implementation.

\section{Participant interviews}

Participants were interviewed to explore their lesson plan writing experiences in the methods course. The participants were interviewed twice during each semester using semistructured but open-ended questions that allowed the interviewees to contribute to the researchers' understanding of their experiences.

Lesson plans using the revised instructional framework. Lesson plans were collected throughout the study. The lesson plans were created as one of the course requirements but not analyzed until the end of each semester after grades were assigned.

\section{Reflective pieces}

The participants wrote their reflective piece at the end of each semester because I first wanted them to experience the lesson writing and implementation process. The reflective piece focused on participants' insights about the inclusion of the four components in the lesson plans and implementing these lesson plans in the field.

\section{Data Analysis}

The analysis of qualitative data followed a procedure recommended by Strauss and Corbin (1998). The procedure consisted of using the constant comparative method that facilitates codifying the information, identifying categories and themes, triangulating through multiple participants and making comparisons between participants' interviews and reflective pieces (Bogdan \& Biklen, 1998). Therefore, pre-service teachers' written pieces, interviews, and 
lesson plans were coded and analyzed inductively to generate major categories. The categories were compared to generate the major themes. The data was analyzed in distinct stages and each stage used the data to test and negate or validate the meaning given to the interpretation of data.

\section{Findings}

A summary of the participants' experiences and my reflective thoughts on their experiences is presented in Table 1. 
Table 1: Summary of findings

\begin{tabular}{|c|c|c|c|}
\hline & Research question & Theme 1 & Theme 2 \\
\hline \multirow[t]{2}{*}{1.} & $\begin{array}{l}\text { Participants' } \\
\text { experiences with } \\
\text { lesson plan writing }\end{array}$ & $\begin{array}{l}\text { Participants' demonstrated } \\
\text { increased comfort level in } \\
\text { integrating science content } \\
\text { and pedagogy }\end{array}$ & $\begin{array}{l}\text { Participants' experienced both } \\
\text { successes and struggles in } \\
\text { incorporating the new } \\
\text { instructional framework for } \\
\text { lesson planning }\end{array}$ \\
\hline & $\begin{array}{l}\text { My reflection on } \\
\text { participants' } \\
\text { experiences }\end{array}$ & $\begin{array}{l}\text { The revised format } \\
\text { successfully provided a space } \\
\text { in my methods course to } \\
\text { meaningfully engage the } \\
\text { participants in PCK }\end{array}$ & $\begin{array}{l}\text { Despite the revised } \\
\text { framework being successful, } \\
\text { it was a steep learning curve } \\
\text { for many participants }\end{array}$ \\
\hline \multirow[t]{2}{*}{2.} & $\begin{array}{l}\text { Participants' } \\
\text { experiences with } \\
\text { lesson plan } \\
\text { implementation }\end{array}$ & $\begin{array}{l}\text { Participants' perceptions } \\
\text { about lesson plan } \\
\text { implementation were mostly } \\
\text { positive. Many participants } \\
\text { identified a disconnect } \\
\text { between lesson plan writing } \\
\text { and teaching experiences }\end{array}$ & $\begin{array}{l}\text { Participants shared positive } \\
\text { experiences in lesson plan } \\
\text { implementation in the field. A } \\
\text { few participants identified } \\
\text { additional nuanced elements } \\
\text { and provided further } \\
\text { suggestions }\end{array}$ \\
\hline & $\begin{array}{l}\text { My reflection on } \\
\text { participants' } \\
\text { experiences }\end{array}$ & $\begin{array}{l}\text { Participants perceived the } \\
\text { revised instructional } \\
\text { framework to be helpful. I } \\
\text { need to find ways to bridge } \\
\text { this disconnect and at the } \\
\text { same time share the } \\
\text { limitations of lesson plan } \\
\text { writing. }\end{array}$ & $\begin{array}{l}\text { I need to find ways to } \\
\text { accommodate the disconnect } \\
\text { identified by a few } \\
\text { participants in the next } \\
\text { version of the instructional } \\
\text { framework }\end{array}$ \\
\hline
\end{tabular}

\section{Results of the First Question: Pre-service Teachers' Experiences With the Lesson Plan Writing Experiences}

Two themes emerged in response to the first focus question: a) increased comfort level in integrating science content and pedagogy; and b) struggles and successes in the lesson planning process.

Theme1:

Increased comfort level in integrating science content and pedagogy. The participants shared the usefulness of the process in increasing their comfort level. As one participant shared:

Given the fact that I had never wrote a lesson plan before, prior to this course, the four components made the process clear and effective. Using the National Science Teaching Standards were essential in developing my lesson plans...By using the standards, I knew I was complying with them. Bloom's taxonomy was also helpful I 
used it as a guide to begin the lesson plans and create one that concentrated on higher-level thinking. The learning cycle was very effective. It allowed me to know exactly what I needed to do next. The concept maps was [sic] a clear way of developing my lesson. (reflective piece, participant 2)

An example of integrating these ideas is demonstrated through an example where participant 16 integrated the NSES and Bloom's taxonomy in the instructional objectives:

The students will discover through guided experiments that air takes up space. (Bloom's Taxonomy, Cognitive, level 3, [application]; NSES Content Standard A, K-4, Understanding Scientific Inquiry: Scientists use different kinds of investigations depending on the questions they are trying to answer). (lesson plan, participant 16)

Participant 32 delineated each component in the lesson plan and their usefulness:

The national teaching standards were very useful in seeing what in depth concepts and ideas were being taught...Bloom's taxonomy was also very useful in teaching as well as writing the lesson plan. This helped me to see what level of thinking I was expanding my students thinking to, as well as encouraged me to think more into the lesson myself to create higher order questions and activities. The learning cycle style of writing a lesson plan has spilled over to my other lesson plans as well. I feel it is an excellent way to describing the lesson. Finally the concept map. I was weary of this originally but by the end, I understood that it was a way to outlining the information in the lesson, which became very useful when teaching it. (group interview, participant 32)

A concept map created by participant 18 indicates that the participants were able to use it as an organizing tool for the content being taught using the lesson. Figure 1, shows an example of a concept map created by one participant: 


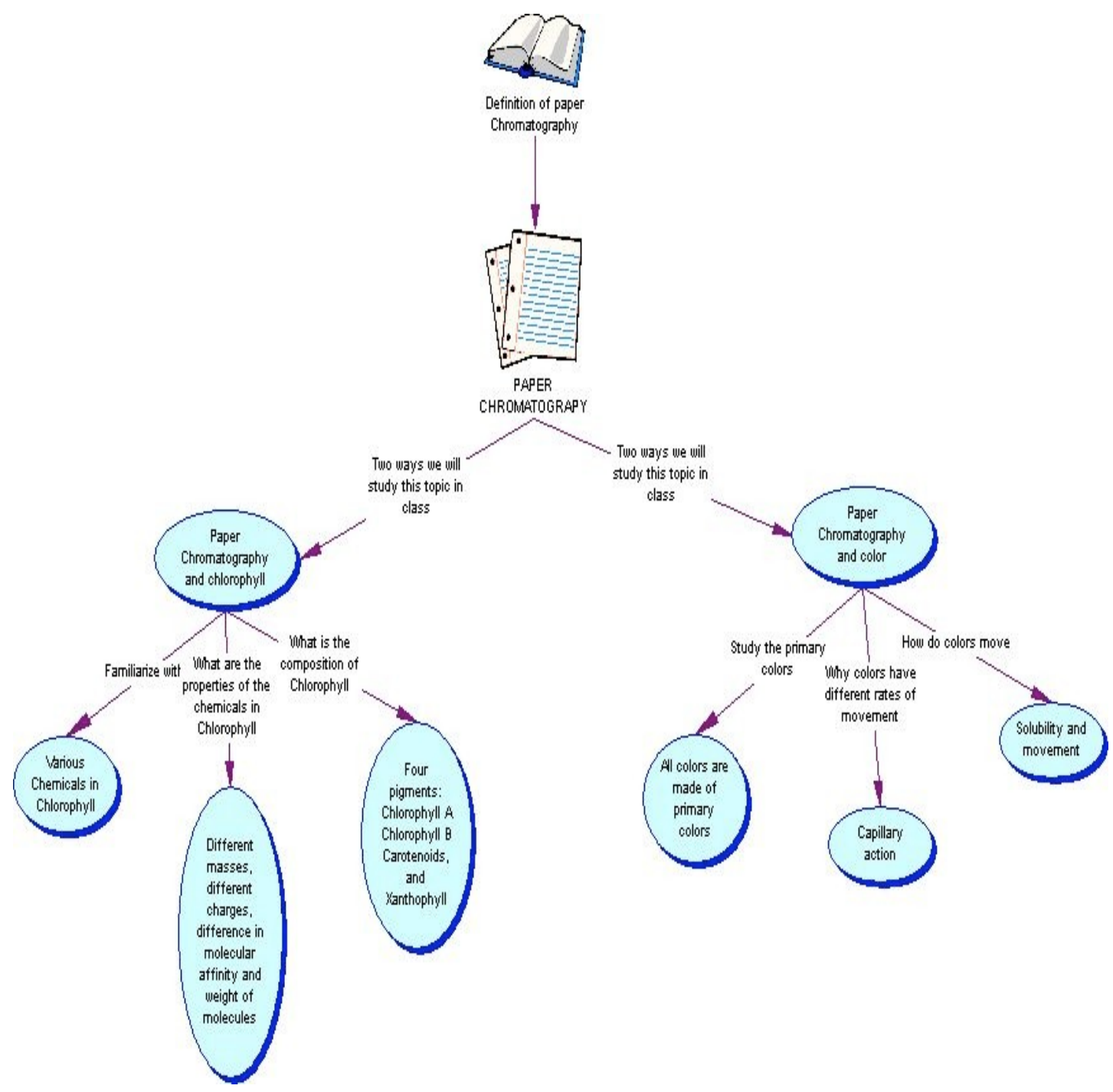

Figure 1: Example of a concept map from a lesson plan (participant 18)

Similarly, an abridged version of the instructional process using the 'learning cycle' in a participant's lesson plan clearly indicates that the participants' felt comfortable in integrating content and pedagogy. Here is an example of the instructional process from participant 16:

\section{Explanatory Hands-On Phase}

Ask each child to kneel down. Put a piece of paper with cereal on it in front of each child (You can use different kinds of cereal to simulate abundant or limited browsing). Tell the children that they are deer, grazing in an open field. They should put their heads down like deer and eat. Appoint one deer to walk among them and act as a lookout (The first time through you can just let them all browse and see what happens without the lookout) When the lookout 
senses danger (a child who has a picture or name of a predator attached to his/her body), the lookout deer raises his white tail (a hand-held flag). The feeding deer must stop eating and flee to SAFETY (a predetermined, marked spot). The predator may tag deer, thus "killing" them. Discuss the action before allowing other students to become predator(s) and the lookout deer. The situation can be change by blindfolding one or more of the deer, having some deer be crippled or old (slower), sick, etc.

\section{Concept Development Stage}

- Monitor the students as they are performing the activity, and continue to give them directions on what to observe. Ask the students what they notice about the deer that are crippled or old? What happens to them when predators come?

- Ask the students if they know what animals might be predators of deer? Besides predators, what other factors can cause the deer population to decrease? What are some factors that cause the deer population in our communities to decrease? What are some things we can do to ensure the safety of deer?

- Encourage the children to talk about ways the deer can protect themselves against predators. What types of defense mechanisms do deer posses?

\section{Concept Application Phase}

After the students complete the activity, have them sit back down at their desks, and begin a discussion with the students by asking the students some of the following questions:

- camouflage (for both predator and prey)

- other adaptations: quick runner, hooves, ruminant vs. carnivore sense of smell, signals, size of ears, eyes, etc. (lesson plan, participant 16)

As I reflected on the participants' experiences, I felt that participants felt confident in their lesson plan writing abilities in science and were actively integrating science content and pedagogical skills. Participants shared that working with the four components allowed them to not only become more confident in integrating science content and pedagogy but also allowed them to critically analyzed the quality of their own lesson plans. They recognized that the each component led to a deeper understanding of instructional/performance objectives, the interplay between objectives, instructional process, and the embedded content. They also identified the interconnectedness of these four components and its implications for successful science teaching and facilitating students' understanding of science concepts. This in turn led to increased comfort level in teaching science. As one participant specifically commented, "I am much more confident in the substance of my lesson plan of integrating these four components, it increased my comfort level" (reflective piece, participant 1). 


\section{Theme 2: Struggles and Successes with the Integration of the Four Components in their Lesson Plans}

The participants' experiences were both rewarding and challenging in integrating the four components of the instructional framework. For example, one participant shared that the National Science Education Standards (NSES) were vague, "the National Science Teaching Standards were hard to incorporate into my lesson plan. The standards were not clear and they did not give a good description (interview, participant 6)". However participants' comments in the reflective pieces indicated that the use of NSES in their lesson plans increased their level of comfort. As one participant specifically indicated, "on going back to the standards I also feel that they are necessary because they serve as guidelines for teaching science and without guidelines pre-service teachers may just teach anything and could possibly be unnecessary or inappropriate (reflective piece, participant 25)". In summary, the participants indicated that although they saw a need and the usefulness in implementing NSES, they felt that the standards in their current form were not easy to use.

Participants indicated that Bloom's taxonomy was a useful tool in the lesson planning experience, "It gave me a clean cut idea of what type of cognitive actions I was searching for [it] urged me to change certain things in my lesson to incorporate all the components of Bloom's taxonomy" (reflective piece, participant 19). In terms of creating concept maps, many participants perceived that the concept maps were useful and felt comfortable in designing them. Their high comfort level could be attributed to their prior experiences with designing concept maps in other methods courses. This was indicated in their reflective pieces. As one participant indicated, "I think concept maps are helpful too. It helps me to stay organized and helps me to make sure that I do not forget certain aspects that are important to the lesson (reflective piece, participant 16)". It necessarily did not mean that all the participants found it useful in their own lesson planning experience, as one participant indicated, "A concept map may be good to share with students but I am more of a linear person so they do not help me in the implementation of the lesson content (reflective piece, participant 11)". Similarly, another participant found that incorporating the concept map did not add any value to her teaching, "I feel the concept map was not as useful as the other because I don't feel it added in teaching (reflective piece, participant 7)".

The participants' responses to incorporating the learning cycle in the instructional process indicated that it helped them stay focused, organized, and meet the objectives of the lesson. As one participant commented, "the Learning Cycle ensures that your objectives are included somewhere in the lesson and that the students are responsible for learning the material that they need to learn (reflective piece, participant 15)". Similarly, another participant shared similar thoughts, "I really liked this way of writing a lesson. I thought it was clear and effective and helped me teach my lesson (personal Interview, participant 38)". In summary, many participants saw a value in using the 'Learning Cycle' to organize the instructional process of their lesson plans. The responses indicated that the participants faced an initial struggle about the integration process however they perceived the value of including all four components in their lesson plans:

I feel like I was able to create a quality lesson plans using this technique. I don't know that as a teacher I will be able to create something of that length and detail for every lesson, but I feel that it is extremely important and valuable to go through the process of creating the lesson plans so that I will be able to repeat the process if needed. (personal interview, participant 7) 
In making sense of participants' successes and challenges, I knew that the process of writing the lesson plans would be challenging. Students had communicated one of their challenges with the lesson plan writing experiences in the first semester on integrating Bloom's taxonomy in the instructional process. I had created this requirement in the first version of the instructional framework. However, the feedback from the students in the class indicated that they felt overwhelmed by this requirement. Therefore, the following semester I only required the students to integrate the Bloom's taxonomy in the instructional/performance objectives. The feedback from the second group of students was positive; however, many of them still grappled with the integration of all four components in the lesson plans in an effective manner. Therefore, I allowed students to submit the first lesson plan for feedback only (no grades). Some students did take advantage of this opportunity and used the feedback before submitting the final version of their first lesson plan. I plan to carry out this practice in future courses so that the students feel comfortable in not only becoming familiar with the revised instructional framework but they also become fluent in integrating it into their future lesson plans. As each semester progressed, I discovered that the participants became more sophisticated with each lesson plan after receiving feedback from me. They struggled less and less in integrating the four components and gradually became more fluent and articulate in assessing the quality of their own lesson plans.

\section{Result of the Second Research Question: Pre-service Teachers' Experiences in Lesson Plan I mplementation in the Field}

The second research question focused on the participants' experiences in implementing the lesson plans in the field during their field placements. The analysis of the data generated two themes: 1) participants' perceptions of lesson plan implementation in the field; and 2) participants' experiences with lesson plan teaching in the field.

\section{Theme 1}

Participants' perceptions of lesson plan implementation. The data from the participants' interviews and reflective pieces prior to their placement in the field indicated that many participants perceived that the lesson planning writing experiences will translate positively in the field. This theme emerged during data analysis even though I was more interested in finding out the participants' actual experiences in the implementation. As one participant indicated:

I do believe this lesson plan will help [me] to a more efficient implementation of my lesson. I felt a little more ready and comfortable to teach a great lesson. Because I already thought before hand of the higher level questioning I was going to do. (personal interview, participant 15)

Similarly, another participant shared, "I am really glad that I was educated to incorporate these elements into my lesson plans. Having written a lesson plan made me feel prepared when implementing my lessons in the classroom (reflective piece, participant 32)". However, one participant argued that the lesson writing experiences may not translate into successful implementation in the field:

I don't think the lesson plans will help in implementation in the field. The lesson plans help as far as incorporating different standards effectively. This gave me practice in doing that but I don't think it will effect (sic) how I will teach the lesson in the field. The research-based lesson plans help me with planning a good, sound lesson more than how to teach the lesson. (reflective piece, participant 34) 
Similarly, participant 26 made a distinction between writing and implementing lesson plans:

I found that creating a lesson plan and implementing it is not the same thing. Allowing us to implement a lesson plan will really help me put things in perspective. In the sense that, it will help me improve and modify the written lesson plans. (personal interview, participant 26)

Other participants, on the other hand, did feel that process of designing the lesson plans will positively impact the implementation process in the field. As one participant indicated:

I truly believe by using these 4 components you will have a great lesson plan. I have done many different lesson plans, but this seems to be the most structured and of the most importance. The lesson plan shows the importance of incorporating standards and higher level thinking. I think by using these four components increases your comfort level in teaching of science in an elementary classroom. (reflective piece, participant 28)

In reflecting on the participants' experiences, I found that most participants valued writing these lesson plans and appreciated the importance of effective implementation in the field. However, some participants did make a distinction between writing and teaching lessons in the field. As I reflected on how to make sense of this distinction, I reflected on two issues: a) the first issue made me consider the fact that the revised instructional framework may still be missing key pieces that could be useful for successful implementation of these lesson plans in the field. If so, what were these pieces and how could I (or could I) integrate them into the revised framework without making it any more challenging for the participants? I decided to look at the data from the actual implementation of the lesson plans to find some of these missing pieces and how they could be integrated in the future versions of the instructional framework. For more information, please see the discussion and implication sections of this paper; b) the second issues made wonder whether lesson planning (no matter how extensive it is) could ever capture the lived experience and the essence of actual teaching in a classroom. My own response is - probably not, but I do strongly believe that effective lesson planning can prepare a pre-service teacher for successfully experiences in the classroom. The participants who were 'sensing' this disconnect between the actual writing and teaching could be categorized as being more sophisticated in the 'art and craft' (Parker, 1998) of teaching. They recognized the limitations of the lesson plan writing experiences early on in their teaching career. Feedback from these participants would benefit this process immensely as I try to capture and integrate this nuanced disconnect or understandings into the next version of the revised framework.

Additionally, I may need to present the goals of the lesson plan writing experiences (i.e. increasing their PCK) explicitly to the pre-service teachers and also be more proactive in recognizing and sharing the shortcomings of the lesson plan writing process in itself. I need to share with the pre-service teachers the limitation of this process in not capturing the lived experiences of a classroom. This may allow the participants to focus on developing their PCK for actual lesson implementation in the field. Based on the data analysis, however, I can confidently argue that a majority of participants, many of who struggled with the content mastery and pedagogical skills, saw a high correlation between lesson plan writing and successful implementation of the lesson plans in the field.

Participants' experiences with lesson plan teaching in the field 
The participants shared their experiences in teaching the lesson plans in the field. Many participants found that one or more components of the lesson plans were helpful. As one participant indicated:

When teaching this lesson I was not nervous, scared etc...I was prepared...because of the detail put into writing the lesson. The 'process' of preparing for a lesson by doing research and writing (using the four components) is imperative in our pre-service years. Though the class went astray, I was comfortable because I knew my purpose in front of the class. (personal interview, participant 9)

Another participant reflected on her post-teaching experience, "I enjoyed integrating Bloom's taxonomy because it forced me to make some complete lesson plans. For example, I would write specific questions that I would want to ask the students" (group interview, participant 16). Another participant shared in her post-teaching interview session, "I spent a lot of time on lesson planning in this course than in any previous courses. But I think that my lesson plans were much more ready for using in the actual classroom" (personal interview, participant 7). Another participant focused on science content and student motivation:

I found [my] lesson plan much better because I knew exactly what content and areas of the content I would teach to the class...I wrote a lesson plan and was only able to implement half of it in the classroom. Some students were clearly motivated, others were not. However, this lesson plan allowed students to say their background knowledge and work off of the background knowledge. (group interview, participant 12)

In reflecting on participants' experiences, I discovered that as participants taught these lesson plans, they identified many nuanced aspects of teaching that were not explicitly addressed in their written lesson plans. As many participants indicated, managing the classroom environment/classroom management or motivating the students became a challenge as they taught their lesson plans. However, despite these challenges, many felt a high level of confidence and comfort in getting up in front of their students and negotiating science teaching. Indications of disconnect between the lesson plan writing and lesson plan implementation through data analysis reinforces my belief that I need to be explicit about the goals of the lesson plan writing. It is clear that some pre-service teachers identified it during the writing process itself while for others it became more apparent during the teaching of these lesson plans. Nevertheless, both sets of participants indicated that the lesson plan writing process contributed not only toward their increased comfort and confidence in teaching science but also contributed positively toward a refined understanding of PCK. In summary, many participants were able to successfully implement the lesson plans in their field experience.

\section{Discussion and I mplications}

The primary focus of this paper was to intentionally engage in an inquiry about my own practice. I wanted to discover how modifying one aspect of my teaching practice in the science methods course would lead to the intended goals, i.e., enhancing pre-service teachers' comfort with science content and pedagogical skills. The modification in my teaching practice was done by introducing a revised lesson planning framework. The lesson planning writing experiences enabled pre-service teachers to develop content driven and 
pedagogical sound lessons, engaged them in reflecting on their experiences, and sharing their experiences through personal interviews and reflective pieces. Specific components that made this project sound was the duration of the data collection and working with three groups of pre-service teachers over a period of three semesters, the opportunity for preservice teachers to teach the lesson plans in the field, and infusion of content and pedagogy.

The findings indicated that the benefits of the lesson plans are perceived in two areas: 1 ) increased confidence and comfort in elementary pre-service teachers' abilities in integrating content and process; and 2) ability to integrate the literature to successfully teach science lessons in the field. As I interpreted the findings that dealt with the challenges faced by the participants, I found that some of the challenges were related to one of the required components for the lesson plans. The findings indicate that many participants found the NSES standards to be vague and broad and felt that they lacked clear guidelines for integration in the curricular materials such as lesson plans. They felt that NSES were too open-ended in comparison with the state learning standards. Therefore, the participants looked upon this as a weakness of NSES. The participants indicated that the state learning standards could be incorporated easily into the learning objectives in the lesson plan where the incorporation of NSES was open to many interpretations. However, other participants found that NSES could be used as a framework and state standards could be used as specific guidelines for writing lesson plans. This is supported by Rodriguez's (1997) claim that the greatest strengths of NSES is that they provide a cohesive vision and guidelines on what science teaching and learning should be and have represented consensus of the nation's science education community. In reflecting on this requirement of the revised instructional framework, I have now decided to allow students to incorporate both national and state standards. In addition, I now allow students to sometimes use only state standards if they have been revised and align well with the national standards. I make this recommendation while keeping in mind that our pre-service teachers may ultimately be required to meet state standards. Therefore, allowing them an opportunity to use state standards makes the transitions from pre-service to in-service teachers easy.

The findings indicate that the majority of participants found that incorporating the learning cycle, Bloom's taxonomy, and the concept map in their lesson plans was easy and led to increased comfort level in writing and teaching science lessons. A few participants did not find concept mapping to be very useful in organizing the science content in the lesson plan. These participants felt that the use of concept mapping did not align will with their learning style. In this study, the participants wrote the last two lesson plans in the context of their field setting and planned them around their classroom setting, identified topics to be taught (in consultation with their cooperating teacher), and targeted the student population.

Therefore, there was a context and topics to guide the lesson planning process. However, it is possible that not all participants got to plan a 2-week unit thus they didn't find concept mapping as useful in guiding their individual lesson plans. In summary, I have decided to continue to use all the four components of the revised framework in my methods course.

In terms of writing and implementation of lesson plan in the field, most participants felt that the writing the lesson plans facilitated successful implementation in the field as a result of attention to details in writing the lesson plans. However, a few participants felt that there was disconnect in the writing and implementation aspect of the lesson plans. They felt that writing a detailed lesson plan does not automatically lead to successful teaching in the classroom as one has to take into account student motivation, classroom management issues, and resources available in the classroom. As I think about these issues, I feel that I 
need to explicitly cover these aspects in the instructional process of lesson plan writing component. For example, the concept introduction stage of the learning cycle could explicitly state ideas to generate student interest or motivate students in the classroom. Similarly, one aspect of the self evaluation could focus on classroom management so that the pre-service teachers can integrate the classroom management ideas into their lesson plans. This will allow the pre-service teachers to see the connection between the writing and teaching aspect of the 'instructionally designed' lesson plans. However, I need to help preservice teachers' understand that writing the lesson plans using the revised instructional framework is not going to replace the actual teaching experiences in the classroom. I also need to remind them that they may need to make modifications to their lesson plans and teaching depending on the student population, school culture, classroom contexts and various other factors that guide the complex process of teaching and learning.

The analysis of the results indicate that there is a need for incorporating interventions such as this one and many others that target the pre-service teachers' low comfort level in science teaching in elementary school settings. We know that many pre-service elementary teachers hesitate to bring science to their classroom due to their low comfort levels. This intervention allowed the participants to become more fluent in PCK and it also increased their confidence in teaching science. Incorporating new practices such as this one provide a 'space' for the pre-service science teachers to master the needed science background knowledge as well as pedagogical strategies. I mplementing, discussing and sharing such interventions will not only benefit the pre-service science teachers but the science education communities as well.

I do want to share the methodological limitations of the study. As any other qualitative study, I can not argue that the results of this study can be generalized to any other population and/or setting. Even though the sample size was large $(\mathrm{N}=48)$, the findings do not allow for widespread generalization as the participant interviews, reflective pieces, and the content analysis gave insights into these pre-service teachers' experiences with the revises instructional framework in my methods course.

\section{Recursive Reflections}

I have informally engaged in SoTL conversations in the past with students and colleagues as I explored ways to implement new ideas and strategies in my courses. In this paper, as part of my engagement in SoTL, I not only formalized and documented the process but I also placed my practice in the public sphere for scrutiny through the peer-review process by making it available to others in the field. This enabled me to accomplish two important objectives: a) establish praxis in SoTL to inform my own practice by engaging my students and myself in critical reflections; and b) engage in a scholarly inquiry to meet my career goals by meaningfully engaging pre-service teachers in the scholarship of teaching. In addition, I was able to tie the SoTL framework with Shulman's PCK ideas. I used Shulman's PCK ideas to bridge the specialized knowledge for teaching and subject matter in my method course. Engaging in this inquiry allowed me to create a 'space' in my course for the pre-service teachers to negotiate PCK by participating in the revised lesson planning framework. SoTL, on the other hand, provided a 'space' where I could engage in a scholarly inquiry by analyzing pre-service teachers' reflections on their engagement with the revised framework, present this inquiry in a public sphere, and share it with others. 


\section{References}

Abell, S. K. (2007). Research on science teacher knowledge. In S. Abell, K. \& N. Lederman, G. (Eds.), Handbook of Research on Science Education. Mahwah, NJ: Lawrence Erlbarum.

American Association for the Advancement of Science (1989). Science for all Americans: A project 2061 report on literacy goals in science, mathematics, and technology. New York: Oxford University Press.

American Association for the Advancement of Science (1993). Project 2061: Benchmarks for Science Literacy. New York: Oxford University Press.

Archbald, D. A., \& Porter, A. C. (1994). Curriculum control and pre-service teachers' perceptions of autonomy and satisfaction. Educational Evaluation and Policy Analysis 16 (1), 21-39.

Ajzen, I., \& Madden, T. J . (1986). Prediction of goal-directed behavior: Attitudes, intentions, and perceived behavioral control. Journal of Experimental Social Psychology, 22, 453-474.

Ajzen, I. (1996). The directive influence of attitudes on behavior. In P. M. Gollwitzer \& J. A. Bargh (Eds.), The psychology of action: Linking cognition and motivation to behavior (pp. 385-403). New York: Guilford Press.

Bandura, A. (1986). Social foundations of thought and action: A social cognitive theory. Englewood Cliffs, NJ : Prentice-Hall.

Bandura, A. (1997). Self-efficacy: The exercise of control. New York: W. H. Freeman.

Ball, A., \& Washburn, S. G. (2001). Teaching students to think: Practical applications of Bloom's taxonomy. The Agricultural Education Magazine, 74 (3), 16-17.

Beck, J., Czerniak, C. M., \& Lumpe, A. T. (2000). An exploratory study of teachers' beliefs regarding the implementation of constructivism in their classroom. Journal of Science Teacher Education, 11, 323-343.

Bencze, L. \& Hodson, D. (1999). Changing practice by changing practice: Toward more authentic science and science curriculum development. J ournal of Research in Science Teaching, 36, 521-539.

Bogdan, R. C., \& Biklen, S. K. (1998). Qualitative research for education: An introduction to theory and methods ( $3^{\text {rd }}$ ed.). Boston, MA: Allyn and Bacon.

Butler, M. B. (1999). Factors associated with students' intentions to engage in science learning activities. J ournal of Research in Science Teaching, 36(4), 455-473.

Caprio, M.W., Powers, P, Kent, J.D., Harriman, S., Snelling, C., Harris, P., \& Guy, M. (1998). A path toward integrated science-the first steps. J ournal of College Science Teaching, 27 (6), 430-435.

Cox, C., \& Carpenter, J. R. (1989). I mproving attitudes toward teaching science and reducing science anxiety through increasing confidence in science ability in an in service elementary school pre-service teachers. J ournal of Elementary Science Education 1(2), 14-34.

Czerniak, C. M., \& Lumpe, A. T. (1996). Predictors of science fair participation using the theory of planned behavior. School Science and Mathematics, 96, 355-361.

Engelhart, M.D., Furst, E. J., Hill W.H., \& Krathwohl, D.R. (1956). B. S. Bloom (Ed.) Taxonomy of objectives: The classification of educational goals. Handbook 1: Cognitive domain. New York: David McKay.

Gallagher, S. A. (1994). Middle school classroom predictors of science persistence. J ournal of Research in Science Teaching, 31 (7), 721-734.

Guba, E. G., \& Lincoln, Y. S. (1994). Competing paradigms in qualitative research. In N. K. Denzin \& Y. S. Lincoln (Eds.), Handbook of Qualitative Research. Thousand Oaks: Sage. 
Haney, J. J., Czerniak, C. M., \& Lumpe, A. T. (1996). Teacher beliefs and intentions regarding the implementation of science education reform strands. J ournal of Research in Science Teaching, 33, 971-993.

Hassard, J . (2005). The art of teaching science: Inquiry and innovation in middle school and high school. New York: Oxford University Press.

Hooks, b. (1994). Teaching to transgress: Education as the practice of freedom. NY: Routledge.

Huber, M. T. and Hutchings, P. (2005). Surveying the scholarship of teaching and learning. The Advancement of Learning: Building the Teaching Commons ( $p p$. 1-16). San Francisco: Jossey-Bass.

Johnson, J. (1999). Exploring inspiration. Learning and Leading with Technology 27(3), 5960.

Jones, C., \& Levin, J. (1994). Primary/elementary pre-service teachers' attitudes toward science in four areas related to gender differences in students' science performance. J ournal of Elementary Science Education, 6, 57-59.

Krathwohl, D. R. (2002). A revision of Bloom's taxonomy: An overview. Theory into Practice, 38 (4), 212-218.

Lumpe, A. T., Czerniak, C. M., \& Haney, J. J . (1998). Science teacher beliefs and intentions regarding the use of cooperative learning. School Science and Mathematics, 98, 123135.

Lumpe, A. T., Haney, J. J., \& Czerniak, C. M. (2000). Assessing teacher's beliefs about their science teaching context. J ournal of Research in Science Teaching, 37 (3), 275-292.

Miles, M. B., \& Huberman, A. M. (1994). Qualitative data analysis: An expanded sourcebook. Thousand Oaks, CA: Sage Publications.

National Research Council (1996). National Science Education Standards, Washington, DC: National Academy Press.

Novak, J. D. (1998). Learning, creating, and using knowledge: Concept maps as facilitative tools in schools and corporations. London: Cornell University Press.

Novak, J. D., \& Gowin, B. D. (1984). Learning how to learn. New York: Cambridge University Press.

Pajares, M. F. (1992). Pre-service teachers' beliefs and educational research: Cleaning up a messy construct. Review of Educational Research, 62 (3), 307-332.

Parker, P. (1998). The courage to teach. San Francisco, CA: Jossey-Bass.

Patton, Q. M. (2002). Qualitative research and evaluation methods. ( $3^{\text {rd }}$ ed.). Thousand Oaks, Ca: Sage.

Radford, D. L. (1998). Transferring theory into practice: A model for professional development for science education reform. Journal of Research in Science Teaching, $35,73,88$.

Rakow, S. (1999). NSTA'S response to the TIMSS. The Science Teacher, 66(1), 30-33.

Riggs, I. M., \& Enochs, L. M. (1990). Toward the development of an elementary teacher's science teaching efficacy belief instrument. Science Education, 74, 625-637.

Rodriguez, A. J. (1997). The dangerous discourse of invisibility: A critique of the national research council's national science education standards. J ournal of Research in Science Teaching, 34 (1), 19-37.

Rubba, P. A. (1992). The learning cycle as a model for the design of science teacher pre service and in service education. Journal of Research in Science Teaching, 3 (4) 97 101.

Rye, J. A., \& Rubba, P. A (1998). An exploration of the concept map as an interview tool to facilitate the externalization of students' understanding about global atmospheric change. J ournal of Research in Science Teaching 35(5), 521-546.

Shrigley, R. L., Koballa, T. R., \& Simpson, R. D. (1988). Defining attitude for science 
educators. J ournal of Research in Science Teaching, 25, 659-678.

Shulman, L. (1987). Knowledge and teaching: Foundation of new reform. Harvard Educational Review, 1, 1-22.

Simonis, D., \& Cumo, J. (1993). Gender effects of learning cycle method and student learning in seventh grade science classes. Transforming Science and Technology:

Our Future Depend on It. S. H. A. Holmes. Waterloo, Canada, University of Waterloo.

Simpson, R. D., \& Troost, K. M. (1982). Influences on commitment to and learning of science among adolescent students. Science Education, 66, 763-81.

Strauss, A. L., \& Corbin, J. M. (1998). Basics of qualitative research techniques and procedures for developing grounded theory. Thousand Oaks: Sage Publications.

The National Science Education Standards: A Vision for the Improvement of Science Teaching and Learning (1998). An NSTA Position Statement. Science Teacher, 65 (5), 51-53.

Towbridge, L. W., Bybee, R. W., \& Powell, J. C. (2004). Teaching secondary school science: Strategies for developing scientific literacy. Upper Saddle River, NJ: Pearson.

Willerman, M., \& Harg, R. A. (1991). The concept map as an advance organizer. Journal of Research in Science Teaching, 28 (8), 705-711.

Woods, C. (1999). The Montessori teacher and Bloom's Taxonomy. Montessori Life, 11 (4), 43-45.

\section{Appendix A \\ Guidelines for Creating Lesson plans}

Teacher ............. Date ........ Duration ........ Grade level ........

Tip: To choose a topic, you can use any science textbook, website/s (ask Eric lesson plan website etc.). Please choose topics that allow you to incorporate hands-on/ minds-on activities and/or discrepant events. This lesson plans are for practice only. You will write additional lesson plans on topics being covered in your field placement during the practicum.

\section{a. Title of the Unit}

b. Rationale: An explanation of why the lesson is important and why you chose the particular lesson topic

c. Instructional/ Performance objectives (for students): General statements of what students will learn from this lesson; specific statements should share the details of precisely what students will be able to do as a result of participating in the lesson (using state standards as your objectives will be fine as long as they meet your objectives and are not too broad). Incorporate the following in your objectives as well: National Science Education Standards (NSES) and Blooms Taxonomy: Please incorporate the NSES in each objective. DO NOT list the NSES or Bloom's taxonomy at the end of all the objectives (they should be incorporated AFTER every objective).

d. Background I nformation (content, vocabulary-words and definition, concept map). This is the information that you would expect the teacher (that will be you) to know and master before presenting the lesson. You will also clearly indicate that science content knowledge base that you expect students to master after each 
lesson has been taught. Please CLEARY AND EXPLI CITY identify and include the target audience for the background information. You can have two categories in this section; background information for the teacher and background information for students. If there is an overlap, please indicate. How much of the information do you want students to master? Make sure that the instructional process and the performance specifically covers the background information intended for students.

\section{e. Material and equipment for the teacher/ material for students}

\section{f. Safety notes}

g. Instructional process: Describe what you and your student will be doing during the lesson; specify content and process; provide classroom management suggestions. Please specify teaching and learning strategies, teaching materials and procedure.

Important: Design the instructional process using the LEARNI NG CYCLE (concept introduction, concept development, and concept application).

Organize the instructional process as described below:

Concept introduction: Motivate students and create a desire in students to want to learn science. Communicate to students what content will be covered, why it is important to know it, and how it fits in the real life. Motivation should be dynamic, enthusiastic, stimulating and based on natural interests. Hint: Think about science demonstrations, questions, films, discrepant events, exciting stories, current events, etc.

Concept development: Organize the content in a logical and purposeful manner. Delineate the content and relate it to objectives. Integrate science content to other areas (social studies, home, history, mathematics etc.). Use question-and-answer session; have students summarize the content; indicate what students need to know.

Concept application: Clearly indicate how your students will be applying the concepts in real-life situations.

h. Assessment

What might be examined and what you look for (to inform you about students' progress toward specific objectives)?

Specify mode of assessment/documentation (informal/formal; conferences, oral discussions, anecdotal records, etc.).

\section{Closure}

Conclude or have students wrap up the lesson with reference to performance objectives. You may highlight/summarize what was learned and what may lead to independent/future work.

\section{J. Self Evaluation}

1. Self Evaluation of lessons done on campus prior to actual teaching: What is particularly good about this lesson? What might cause difficulties? What might you want to keep in mind to make things flow smoothly? 
2. During Practicum (this will be done during the practicum) What worked well in the lesson?

What might be changed/altered in future teaching experiences?

What was learned that might inform future lessons?

H. Resources or suggested references that you used to create your lesson plans. 


\section{Appendix B}

\section{Scoring guide for the lesson plan}

1. Introduction (Title, duration of class, grade level, rationale) (1 points)

2. Objectives
a. Bloom's taxonomy integrated in the objectives
(1 points)
b. NSES/State standards integrated in the objectives
(1 points)

\section{Background information}

a. Content information include in the section and the target audience explicitly stated and how the content information will be provided to the target audience (briefly)

(2 points)

4. Instructional process
a. Materials and resources clearly indicated (include all
(1 points)
b. Instructional process is organized using the learning cycle (3 stages)
c. Concept introduction is clearly laid out
d. Concept development is clearly laid out
(2 points)
e. Concept application is clearly laid out
(2 points)

5. Concept map is a representation of the content being covered in the lesson

( 2 points)

6. Strong alignment among the objectives, concept map, and the instructional process

7. Closure/ recap

The lesson plan includes a recapitulation of information

(1 point)

8. Self-reflection is clear, thoughtful, and meaningful

(2 points)

9. Resources/ references

Site the sources that provided the framework for your lesson plans (Websites, the textbook, other resources) 